\title{
Introducing the paradigm of organizational value creation effect on customer loyalty: A case study of Tehran province food industry unites
}

\author{
Maryam Zarandi
}

MA in Business Administration of Allame Tabatabaee University, $R$ \& D manager of Iranian Management System Company ( SAMA)

\begin{tabular}{|c|c|}
\hline A R T I C L E I N F O & A B S T R A C T \\
\hline $\begin{array}{l}\text { Article history: } \\
\text { Received October 1, } 2011 \\
\text { Received in Revised form } \\
\text { November, 14, } 2011 \\
\text { Accepted 15 December } 2011 \\
\text { Available online } \\
\text { 24 December } 2011 \\
\text { Keywords: } \\
\text { Value } \\
\text { Value Creation } \\
\text { Loyalty } \\
\text { Customer Need }\end{array}$ & $\begin{array}{l}\text { Today, organization cannot firmly survive without having a broad captive market. Rather, } \\
\text { through value creation for customers and achieve their loyalty, we can maintain and increase } \\
\text { the existing market share. Providing a specific product or service requires modern ideas and } \\
\text { approaches to be applied in organizations. Resource limitations prevent organizations from } \\
\text { being the best on all value creation contexts; so they must focus on some range of customer- } \\
\text { centric values regarding the given customer groups; because customer needs will change as } \\
\text { time goes by and it requires different kinds of values to be taken into consideration. In this } \\
\text { research, organizational value creation effects on customer loyalty is studied by more recent } \\
\text { and complete customer value model designed by Flint et al. (2010) [Flint et al. (2010). } \\
\text { Customer value anticipation, customer satisfaction and loyalty: An empirical examination. } \\
\text { Industrial Marketing Management, } 40 \text {, } 219-230] \text {. In this regard, some questionnaires are } \\
\text { distributed among a statistical population including } 90 \text { customers of Tehran Food Industries. } \\
\text { Results show that organizational value creation affects on customer loyalty. Among effective } \\
\text { factors, product quality has the most effects on organizational value creation following by } \\
\text { product price, marketing and after-sales services. }\end{array}$ \\
\hline
\end{tabular}

(C) 2012 Growing Science Ltd. All rights reserved.

\section{Introduction}

By liberalization of economic activities and globalization of competition, customers have gotten a different role in organizations. Therefore, by full recognition of customer needs and behaviors and finding top customers, organizations can reach the best level of profitability. In addition to planning some strategies for customer making and transacting with them, organizations have been going to keep their existing customers and make a permanent relationship with them. In other words, organizations are going to embrace the customer lifetime value (CLV).

CLV includes net present value of the cash flows, where an organization can reach depends on its relationship with a customer. Therefore, trying to keep the customers is an economical way attracts

* Corresponding author. Tel. +0989192008394

E-mail addresses: m.zarandi2009z@yahoo.com (M. Zarandi)

C 2012 Growing Science Ltd. All rights reserved

doi: $10.5267 /$ j.msl.2011.12.017 
attention of organizations (Wang et al., 2004). Consequently, in this extra dynamic market, customer expects the best values with appropriate prices from organizations and on the other hand, organizations continuously seek for new methods and innovations for value creation and value presentation; and they even call customer as their "future source of competitive advantage" (La \& Kandampully, 2004). Beside this, analyzing market conditions and customer expectations and providing products/services according to customer anticipated values are very important for the managers (Flint et al., 2010). Many researchers have shown that customer anticipated value is a dynamic and unsteady phenomenon in time so that value creation for customers would be a strong motive that increases customer loyalty.

For an enterprise, customer loyalty is a key in business achievement; and the concept of loyal customer includes increase of profitability and value creation for low prices. Customer making and customer loyalty require hard work; since trade organizations have not mostly noticed modern methods of customer relationship and therefore lost most of their customers, organizations must not consider customer loyalty management as customer profitability management. Loyal customer is very valuable as the great marketer and sales source (Maghsoudi, 2010).

Therefore, loyal customer has a potential to increase market share. In this regard, research centers and organizational marketing development spend so much time to recognize customer future needs, regardless the customer loyalty (Narvar et al., 2004). One of the reasons in which organizations disregard customer loyalty may be the difficulty of measuring the relation of this significant factor with profitability and organizational performance. Another reason in this regard is the difficulty of converting data attributed to customer satisfaction about executive efforts. These kinds of data mostly are intra-organizational based and cannot exactly show what customers want and how they perceive them.

As Gronrooz (1994) said, in service-based environment of today's economy, customer loyalty is grounded on two bases: Technical Quality and Functional Quality. Technical quality includes output and service providing; it is actually what customers receives. On the other hand, functional quality includes the quality of service providing process. In this part, customers have participation in that, relationship between service provider and service receiver is made. A smart organization must understand that recognizing potential customers and knowing their buying behaviors are competitive advantages for the. This competitive advantage can both bring profitability for the organization and make its customers loyal and permanent.

\section{Value \& value creation}

The concept of value is one the most functional terms in management terminology. Value is not what is produced, but what customer receives. In marketing, value includes perceived benefits of products/services quality in relation to their perceived prices. Quality in relation to perceived price is one the indicators by which the customer compares different products/services (Huber et al., 2001). Therefore, value is an especial and empirical concept formed in customer mind (Vargo \& Lusch, 2008). Some authors define customer anticipated value as producer ability to find customer especial requirements and needs which has been created later. For producers, value is created during production process and then in service providing; but for customers, value is a perception or satisfaction of producer activities carried out to provide their actual needs (Sirdeshmukh, 2002). In a 
review of the management literature, three groups of values are described: 1) Shareholder Value which is analyzed by economists and financial analysts; 2) Customer Value which is considered by marketers and in fact is the value created by an organization for its customers; and 3) Organizational Beneficiary Value. In this research, we focus on customer and organizational value creation for customer.

The value created by the organization for its customer includes all arrangements planed for product/service providing to the customer, such as production and marketing costs, after-sales services, etc. Organizations must consider the very important role of customers to recognize their future needs and anticipated values and apply it in their strategic decision making. Value creation have played an pioneering role in competitive market, in that customers would not charge more than paid-up value of products/services (Flint et al., 2010).

To understand value creation, it must be initially described. In all organizational levels, two subjects can be fined about value: benefiting customers with value; and value transfer between customer and organization. Benefiting customers with value includes especial quality or functional characteristics of a product/service, which customers perceived as an organization's activities performed based on their needs; this customer perception lads to value judgment by the organization. The value transfer between customer and organization is also called value exchange; we define value transfer as price paid by the customer in order to use a product/service or actually to use the value of a product/service (Dunn, 2010).

Certainly, in definition of value, it must be noted that value creation depends on relative rate of value obtained by the final customer and such a trend leads to money exchange for the obtained value. In general, it can be said that a product/service creates value for the customers when it has flexibility towards satisfying customer future and present needs.

\section{Customer loyalty}

During the last few decades, marketing managers focused only on customer making and product sales, and sales sector has been considered for making new customers. However, today, marketing includes development and customer retention, which means considering customer satisfaction and perceived quality by customer and then making customer loyal are placed at the peak of the strategic goals of the organization. Marketing is such a skill that makes customers both intra-organizational consultants and extra-organizational supporters. Therefore, making loyal customers have reached an especial position in organizations (Grenroos, 2008).

Making loyal customer means creating a positive attitude in customer mind so that he/she inclines to re-buy a product. Loyalty includes a kind of positive attitude towards a product and showing a supportive behavior for it. But there is a more complete definition for loyalty according to Oliver (1999): "Loyalty is a deeply held commitment to re-buy or re-patronize a preferred product/service consistently in the future, thereby causing repetitive same brand or same brand-set purchasing, despite situational influences and marketing efforts having the potential to cause switching behavior" (Dunn, 2010). In other words, it can be said that loyalty is customer commitment to the producer and his/her unwillingness to search for an alternative product. Requirement for making loyal customers is 
to fully satisfy their needs, value creation for them and recognizing their exact wants, demands, tendencies, abilities and limitations in purchasing products.

By having this information, it is possible to fully recognize factors affecting the consumer behavior and apply them in organizational marketing decision making. Therefore, product/services provided by the organization must be compatible with customer anticipated value. If organizations and enterprises are capable of recognizing and satisfying customer needs, they can easily attract customers and make them loyal and permanent.

\section{Different kinds of customer loyalty}

Customer loyalty can be divided into two levels: Constant Loyalty, and Unstable Loyalty. Constant loyalty is to reach a strong relationship between the customer and the organization; thereby there would be a high honesty, commitment and confidence. In this kind of loyalty, both parties are well satisfied with their relationship. However, in unstable loyalty, despite the customer frequent referring to the organization and rebuying its service/product, there is no strong relationship between them and the customer is not fully satisfied.

This is caused by today's competitive environment and customers inclination to comparing services/products so that a deficiency in product/service providing can decrease customer satisfaction. In such a market that products/services have a substitute, least organizational effort to be distinctive from competitors in market is to consider value creation for the customer and increase customer satisfaction (Rowley \& Dawes, 2000). In general, customer loyalty results from customer satisfaction, but satisfaction does not always lead to loyalty.

The customer may have a relative satisfaction, but lack of alternative product makes him/her an unstable customer. This situation is an alarm for smart organizations, since they will lose their customer once an alternative product is launched to the market. Therefore, by considering customer anticipated value and kind of customer loyalty, organizations can satisfy their customers and cause their unstable customers to be constant ones.

\section{Theoretical paradigm of the research}

In this study, analyzing and evaluating the relation between organizational value creation for the customer and the customer loyalty has been performed by customer value model designed by Flint et al (2010), since this model is a new one and has general variables closed to this research variables. In 2010, some American enterprises have created this model to analyze the relation between customer value, customer loyalty and customer satisfaction. Regarding the above model, organizational value creation is defined as capability of the organization to recognize customer future needs and value creation for the customer which affects on customer perceived value and then through customer satisfaction leads to customer loyalty. In this model, customer perceived value includes his/her perceived value from an organization/enterprise without any concerns about product/service type, quality and price. It is important to mention that according to Flint et al. (2010) customer perceived value cannot directly lead to customer loyalty. Considering this statement, we study the effects of organizational value creation for the customer on the customer loyalty. Customer loyalty is the dependent variable and marketing, after-sales services (including free delivery; withdrawal of defective products, etc.), price and product quality attributed to value creation are independent variables. 


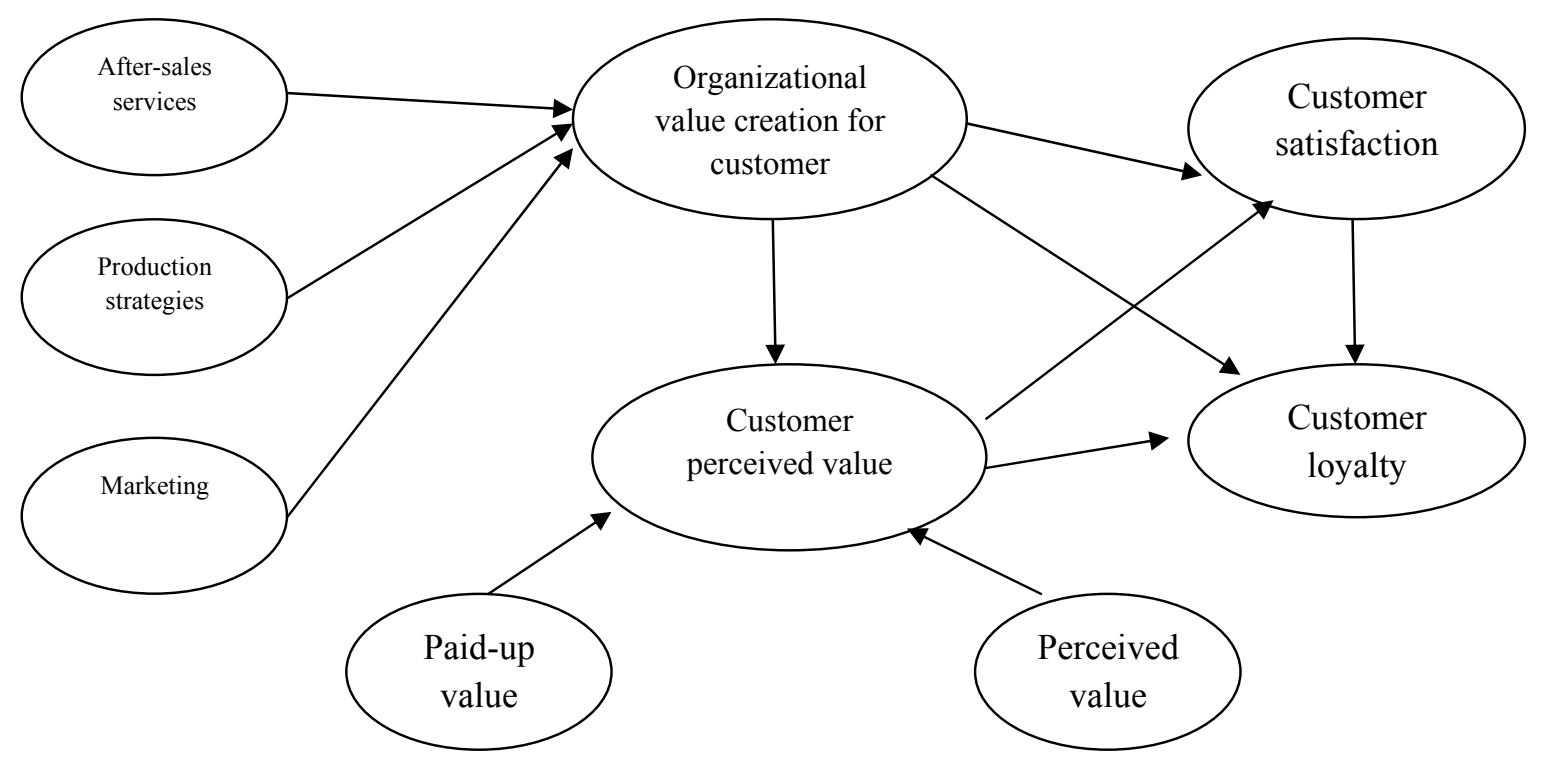

Fig. 1. Organizational value creation developed by Flint et al. (2010)

\section{Research methodology}

This is an applied research in which source collection was performed by library method and data collection for hypotheses testing was done by some questionnaire. By using Cochran formula for sample size determination, a random statistical population of 90 customers from Tehran city was selected. Validity of the questionnaire was evaluated by comments and critics of some professors and academic experts; according to received suggestions, our questionnaire was edited and revised. Reliability of the questionnaire was evaluated by SPSS software and its Cronbach's coefficient alpha was 0.94. In all analysis of this research, significance level has been considered at a 0.5 base and our analytical tool is the regression analysis.

\section{Table 1}

Reliability Coefficients of the Questionnaire

\begin{tabular}{llllll}
\hline Variable Questions & $\begin{array}{l}\text { After-Sales } \\
\text { Services }\end{array}$ & Price & Quality & Marketing & $\begin{array}{l}\text { Organizational Value } \\
\text { Creation }\end{array}$ \\
\hline $\begin{array}{l}\text { Reliability } \\
\text { coefficients }\end{array}$ & 0.768 & 0.779 & 0.908 & 0.708 & 0.812 \\
\hline
\end{tabular}

\section{1 Data Analysis}

Statistical information and data of the research have been collected from 90 food industries customers most of which are females (55\%). The ages of the statistical population were as follows: $36.7 \%$ from 25 to 35 years old, $46.3 \%$ from 35 to 45 years old, $12 \%$ from 45 to 55 years old and $5 \%$ were above 55 years old. Education status of the statistical populations is shown in Fig. 2. 


\section{Educational background}

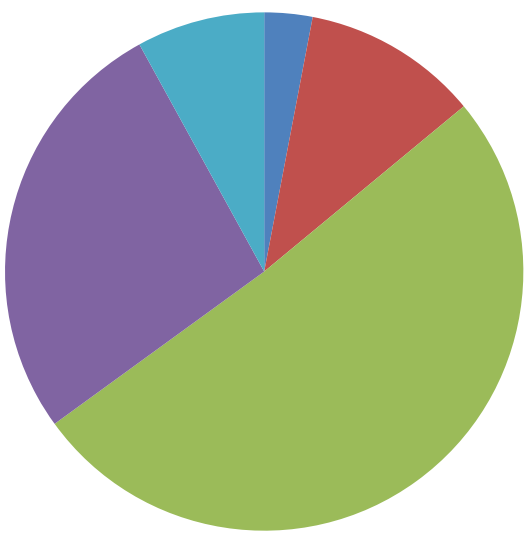

PhD

Masters

- Bachelour's degree

Associates' degree

- High School diplioma

Fig. 2. Distribution of educational background, $\mathrm{PhD}$ (3\%), Master degree 11\%, Bachelor's degree $51 \%$, High school, 8\%, Associate degree 11\%

Regarding model summary shown in Table 2, it can be observed that each 4 predicted variables have $95 \%$ effect on the dependent variable. Observing the determination coefficient shows that these 4 variables totally explain $97 \%$ of the customer loyalty variance as a dependent variable. The remaining $3 \%$ of this variables' variance is explained by other variables out of this model.

Table 2

Model Summary

\begin{tabular}{lllll}
\hline Model & $\mathrm{R}$ & Determination Coefficient & Modified R & Error Estimation \\
\hline 1 & $.950(\mathrm{a})$ & .970 & .912 & .130463 \\
\hline
\end{tabular}

Answers of questions No. 1, 3, 6, $14 \& 22$ are about after-sales services variable. Mean of the answers (3.192) shows that after-sales services averagely affect on organizational value creation for the customer.

Answers of questions No. 2, 8, 11, $17 \& 23$ are about price variable. Mean of the answers (4.074) shows that price have important effects on organizational value creation for the customer.

Answers of questions No. 4, 12, $16 \& 20$ are about product quality variable. Mean of the answers (4.937) shows a very high effect on organizational value creation for the customer.

Answers of questions No. 7, 10, 15, $19 \& 25$ are about marketing variable. Mean of the answers (4.004) shows that marketing highly affects on organizational value creation for the customer.

Answers of questions No. 5, 13, 18, $21 \& 24$ are about the variable defined as organizational value creation for the customer. Mean of the answers (3.901) shows that organizational value creation has medium high effects on organizational value creation for the customer. In other words, for customers, the more the organization value creation, the more the customer loyalty.

As we can see in Table 3 including coefficients, product quality has the most effects on the organizational value creation, thereby if product quality increases by $1 \%$, organizational value creation will increase by $5.08 \%$. 
At the second position, product price $(5.06 \%)$ following by marketing $(3.12 \%)$ and after-sales services $(2.07 \%)$ affect on organizational value creation. In addition, organizational value creation affects on customer loyalty by $3.10 \%$.

Table 3

Coefficients (a)

\begin{tabular}{llllll}
\hline Model & $\begin{array}{l}\text { Unstandardized } \\
\text { Coefficients }\end{array}$ & Standardized Coefficients & $\mathrm{t}$ & & \multicolumn{3}{c}{ Sig. } \\
& & & & & Std. \\
& $\mathrm{B}$ & Std. Error & Beta & $\mathrm{B}$ & Error \\
\hline Constant & .209 & .811 & & 1.79 & .079 \\
Service & 2.07 & .068 & 0.92 & 2.46 & 0.04 \\
Marketing & 3.12 & 0.27 & 0.175 & 3.47 & 0.30 \\
Price & 5.06 & .065 & 0.251 & 3.15 & .03 \\
Quality & 5.08 & .071 & 0.303 & 3.82 & .029 \\
Value & 3.10 & .074 & 0.175 & 2.39 & .022 \\
Satisfaction & 405 & 015 & 0201 & 2.09 & .005 \\
\hline AD & & & &
\end{tabular}

A Dependent Variable: Rate of loyalty of customer

\section{Results of hypotheses testing}

7.1 Research hypothesis: Organizational value creation for the customer affects on customer loyalty.

Results of hypothesis testing performed by regression analysis beside significant level of 0.0022 show that null hypothesis based on ineffectiveness of this variable could be rejected. So, it can be concluded, with a 95\% certainty, that organizational value creation for the customer affects on customer loyalty in this statistical population.

7.2 The first sub-hypothesis of the research: After-sales services affect on organizational value creation for the customer.

Results of hypothesis testing performed by regression analysis and a low significant level of 0.04 $(\alpha=0.05)$ show that null hypothesis based on ineffectiveness of this variable is rejected. Based on these results, it is approved that after-sales services affect on organizational value creation for the customer in this statistical population.

7.3 The second sub-hypothesis of the research: Marketing affects on organizational value creation for the customer.

Results of hypothesis testing performed by regression analysis beside significant level of 0.0022 show that null hypothesis based on ineffectiveness of this variable is rejected. So, it can be said, with a $95 \%$ certainty, that manner of marketing effects on organizational value creation for the customer in this statistical population.

7.4 The Third sub-hypothesis of the research: Product price affects on organizational value creation for the customer.

Results of hypothesis testing performed by regression analysis and also significant level below 0.01 $(\alpha=0.05)$ show that null hypothesis based on ineffectiveness of this variable is rejected. Based on 
these results, it is approved that product price affects on organizational value creation for the customer in this statistical population.

7.5 The fourth sub-hypothesis of the research: Product quality affects on organizational value creation for the customer.

Results of hypothesis testing performed by regression analysis beside significant level of 0.0022 show that null hypothesis based on ineffectiveness of this variable is rejected. Therefore, product quality affects on organizational value creation for the customer in this statistical population.

\section{Conclusion and proposals}

All around the world, organizations try to reach a superior position compared to their competitors through achieving special advantages. On the other hand, customers and consumers always seek for organizations with better and more valuable product/service compared to others. Perception and recognizing of this distinction in customer's mind help selection process of needed service/product and guide customers to make decision for paying more in return for a more valuable product/service.

According to analysis performed in this research and based on Fig. 3, it may be perceived that among all mentioned factors, product quality has the most effects on organizational value creation for the customer and then on customer loyalty. In the next levels, product price, marketing and after-sales services respectively affect on organizational value creation for the customer and consequently on the customer loyalty.

Results of this research are compatible with the research results of Flint at al. (2010) but Flint's research did not include and approved this research hypothesis based on effectiveness of organizational value creation direct effectiveness on customer loyalty.

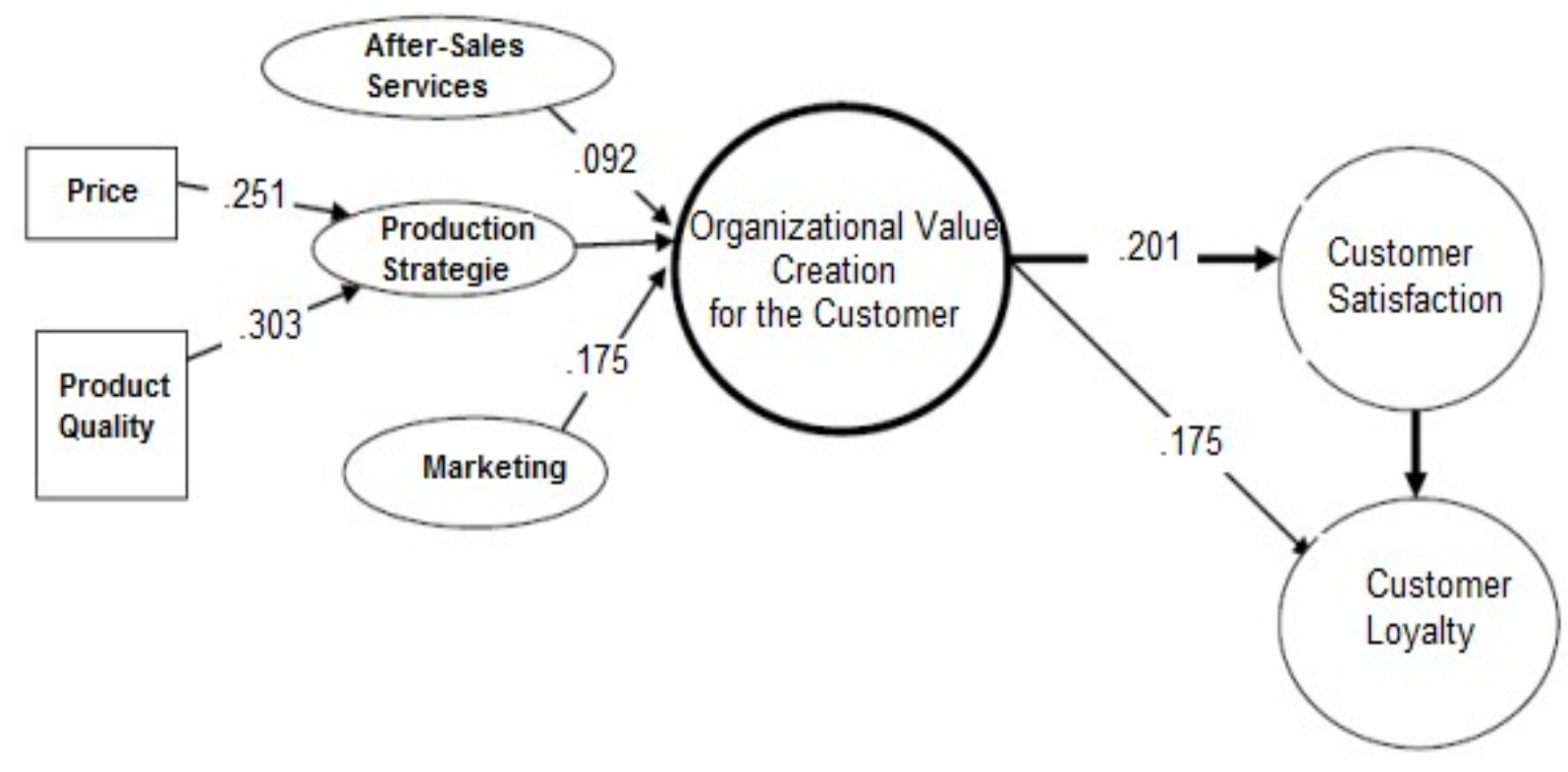

Fig. 3. Paradigm of effectiveness in research perception model 
According to the model applied in this research, for the customer, product quality and price, marketing and after-sales services serve as values result in perception of organizational value creation by the customer, customer satisfaction and decision for rebuying and finally constant loyalty of the customer. Of course, these results are not against research results of Flint at al. (2010), because organizational value creation for the customer increases customer satisfaction, rebuying and consequently customer loyalty. Customers always compare their perceived values from different organizations and finally choose the organization, which creates more values. Organization do not have to only consider the customer anticipated value, because value is dynamic phenomenon and will change in time.

Organizational achievement is obtained when the organization can improve its abilities by creating cross functional teams to recognize customer future needs and values and manage their goal in this regard. Creating such teams in an organization makes it possible for different specialists multidimensionally consideration of customer needs and behaviors and predicting them at present and future.

In such situations, capability of organizational value creation in competitive market is considered as an important competitive advantage. About intra-organizational activities, planning the value map represented as a diagram including organizational value creator activities and factors recognizing their relations in order to decrease costs and to increase value creation for the customer can improve knowledge of managers and employees about any activities' role towards value creations process.

\section{Acknowledgment}

The authors would like to thank the anonymous referees for the constructive comments on earlier version of this work.

\section{Reference}

Dunn, A. ( 2010). The value of coverage in the Medicare advantage insurance market. Bureau of Economic Analysis, U.S. Department to Commerce, 1441 L Street NW, Washington, DC20230, United States.

Flint, D. J., Blocker, C.P., \& Boutin Jr., P. J. (2010). Customer value anticipation, customer satisfaction and loyalty: An empirical examination. Industrial Marketing Management, 40, 219230

Grenroos, C. (2008). From Marketing Mix to Relationship Marketing. Management Decision, 32(2), 4-32.

Grenroos, C. (1994).From marketing mix to relationship marketing: Towards a paradigm shift in marketing. Asia-Australia Marketing Journal, 2, 9-19.

Huber, F., Herrmann, A., \& Morgan, R. E. (2001). Gaining competitive advantage through customer value oriented management. Journal of Consumer Marketing, 18(1), 41 - 53.

Rowley, J., \& Dawes, J. (2000). Disloyalty: A closer looks at non-loyal. Journal of Consumer Marketing, 17(6), 538-549.

La, K.V., Kandampully, J. (2004). Market oriented learning and customer value enhancement through service recovery management. Managing Service Quality, 14(5), 390 - 401.

Maghsoodi, M.H. (2010). The relationship between customer satisfaction and process efficiency and effectiveness. Proceedings of the fourth conference of quality managers.

Narver, J. C., Slater S. F., \& MacLachlan, D. L. (2004). Responsive and proactive market orientation and new-product success. Journal of Product Innovation Management, 21, 334-347.

Oliver, R.L (1999). Whence consumer loyalty?. Journal of Marketing, 63(4), 33-44. 
Sirdeshmukh, D., Singh, J., \& Sabol, B. (2002). Customer trust, value and loyalty in relational exchanges. Journal of Marketing, 66(1).15-37.

Vargo, S.L \& Lusch, R.F (2008). Service-dominant logic: Continuing the evolution. Journal of the Academy of Marketing Science, 36, 1-10.

Wang, Y., Lo, H.P., Chi, R. \& Yang, Y. (2004). An integrated framework for customer value and customer-relationship-management performance. Managing Service Quality, 14(2/3), 169-182. 